\title{
Anti-SLAMF7 Monoclonal Antibody
}

National Cancer Institute

\section{Source}

National Cancer Institute. Anti-SLAMF7 Monoclonal Antibody. NCI Thesaurus. Code C158974.

Any monoclonal antibody directed against the human antigen CS1 (CD2 subunit 1; CRACC; SLAMF7; CD319). 